\title{
PENANAMAN NILAI-NILAI NASIONALISME DAN PATRIOTISME MELALUI MATERI SIKAP SEMANGAT KEBANGSAAN DAN PATRIOTISME DALAM KEHIDUPAN BERMASYARAKAT, BERBANGSA DAN BERNEGARA PADA PEMBELAJARAN PKn DI SMAN 1 PUNDONG
}

\author{
Oleh: \\ Ainun Muchlisatun Rati Sugiman \\ NIM: 1040101485 \\ Universitas Cokroaminoto Yogyakarta
}

\begin{abstract}
Abstrak
Tujuan penelitian ini yaitu: 1) untuk mengetahui sejauh mana pelaksanaan penanaman nilai nasionalisme dan patriotisme dalam materi sikap semangat kebangsaan nasionalisme dan patriotisme dalam kehidupan bermasyarakat, berbangsa dan bernegara dalam pembelajaran PKn di SMA Negeri 1 Pundong. 2) Kendala apa saja yang dihadapi dalam proses penanaman nilai nasionalisme dan patriotisme dalam proses pembelajaran di sekolah 3) Usaha yang dilakukan oleh guru dalam mengatasi kendala-kendala penanaman nilai nasionalisme dan patriotisme di sekolah.

Metode pendekatan yang digunakan dalam penelitian ini adalah metode pendekatan kualitatif. Jenis metode penelitian, peneliti menggunakan metode penelitian deskriptif karena penelitian ini di gunakan untuk menggambarkan, menjelaskan dan menjawab persoalan dalam pelaksanaan penanaman nilai nasionalisme dan patriotisme dalam materi sikap semangat kebangsaan nasionalisme dan patriotisme dalam kehidupan bermasyarakat, berbangsa dan bernegara. Metode pengumpulan data yang digunakan peneliti antara lain observasi, wawancara dan dokumentasi.

Hasil penelitian dapat disimpulkan bahwa proses pelaksanaan penanaman nilai-nilai nasionalisme dan patriotisme melalui pembelajaran PKn dalam materi sikap semangat kebangsaan nasionalisme dan patriotisme dalam kehidupan bermasyarakat, berbangsa dan bernegara dilaksanakan melalui berbagai macam strategi pembelajaran yang diintegrasikan ke dalam rencana pelaksanaan pembelajaran (RPP) dan dilaksanakan dengan berbagai metode ceramah, diskusi, dan tugas berdasarkan perencanaan yang telah dibuat dalam Program kerja. pembelajaran nilai-nilai nasionalisme dan patriotisme juga dilaksanakan melalui berbagai kegiatan yang diadakan oleh sekolah secara langsung seperti upacara bendera, menyanyikan lagu Indonesia Raya dan menyanyikan lagu daerah, memperingati hari-hari besar nasional dan berbagai kegiatan lainnya. Dalam proses penanaman nilai-nilai nasionalisme dan patriotisme pada siswa terdapat beberapa hambatan yaitu kurangnya keteladanan dari figur pemimpin Bangsa yang ada saat ini. Secara khusus dalam proses pembelajaran yaitu minimnya jam pembelajaran pada materi materi sikap semangat kebangsaan nasionalisme dan patriotisme dalam kehidupan bermasyarakat, berbangsa dan bernegara. Upaya untuk mengatasi hambatan dalam proses penanaman nilai-nilai nasionalisme dan patriotisme yaitu bahwa pada setiap proses pembelajaran diselipkan 18 butir karakter dan kegiatan-kegiatan yang dilaksanakan di luar proses pembelajaran yang diselenggarakan oleh sekolah yaitu upacara bendera, menyanyikan lagu Indonesia Raya dan menyanyikan lagu daerah, memperingati hari-hari nasional dan berbagai kegiatan lainnya.
\end{abstract}

Kata Kunci: Nasionalisme, patriotisme, semangat kebangsaan dan pembelajaran PKn 


\section{PENDAHULUAN}

Sejak awal abad ke-20 Republik Indonesia sebagai sebuah Bangsa sesungguhnya sudah merintiskan diri sebagai sebuah negara. Kebangkitan nasional menjadi salah satu titik penting sebagai langkah awal mencapai kemerdekaan. Berikutnya, Sumpah Pemuda adalah momen penting yang menyatukan beragam perbedaan. Hingga akhirnya, 17 Agustus 1945 menjadi titik puncak perjuangan Bangsa Indonesia, yaitu kemerdekaan Bangsa Indonesia. Terhitung lebih dari 70 tahun Bangsa Indonesia menikmati kemerdekaan, tentunya kemerdekaan yang didapat tidak lepas dari perjuangan panjang para pahlawan. Semangat juang dan nasionalisme mereka yang telah membakar dan menimbulkan hasrat untuk merdeka.

Nasionalisme membangun kesadaran rakyat sebagai suatu Bangsa serta memberi seperangkat dan progam tindakan. Nasionalisme dapat dijadikan sebagai dasar pembangunan Negara Kesatuan Republik Indonesia. Nasionalisme itu sendiri berasal dari kata nasional adalah paham atau ajaran untuk mencintai Bangsa dan negara sendiri atau kesadaran keanggotaan dalam suatu Bangsa yang secara potensial atau aktual bersama-sama mencapai, mempertahankan, dan mengabadikan identitas, integritas, kemakmuran dan kekuatan Bangsa (Suprapto, 2007: 38). Sedangkan patriotisme diartikan sebagai semangat atau jiwa yang dimiliki oleh sesorang untuk berkorban atau rela berkorban demi nama suatu Bangsa atau negara (Chotib dkk, 2006: 25).

Paham Nasionalisme merupakan sebuah kejiwaan dimana kesetiaan seseorang secara total diabdikan langsung kepada negara Bangsa atas nama seluruh Bangsa. Munculnya nasionalisme terbukti sangat efektif sebagai alat perjuangan bersama merebut kemerdekaan dari cengkeraman kolonialisme (Syahrial Syarbaini, 2006: 55). Nasionalisme merupakan perpaduan atau sinergi dari rasa kebangsaan dan paham kebangsaan. Kondisi nasionalisme suatu Bangsa akan terpancar dari kualitas dan ketangguhan Bangsa tersebut dalam menghadapi berbagai ancaman. Dengan Nasionalisme yang tinggi, kekhawatiran akan terjadinya ancaman terhadap keutuhan dan kesatuan Bangsa akan dapat dielakkan. Dari Nasionalisme akan mengalir rasa kesetiakawanan sosial, semangat rela berkorban dan dapat menumbuhkan jiwa patriotisme.

Pencapaian tujuan nasional Bangsa Indonesia yang dituangkan dalam Pembukaan Undang-Undang Dasar 1945 merupakan tugas dan kewajiban seluruh warga negara Republik Indonesia. Tanggung jawab dan keikutsertaan warga negara dalam pencapaian tujuan nasional tersebut merupakan perwujudan nasionalisme dalam bentuk kesadaran berbangsa dan bernegara, kecintaan terhadap tanah air, keyakinan terhadap nilai-nilai Pancasila sebagai ideologi, falsafah dan dasar negara, kerelaan berkorban bagi Bangsa dan negara, serta 
kemampuan awal bela negara. Bangsa Indonesia adalah negara yang sangat majemuk dan beranekaragam, baik itu kebudayaannya maupun masyarakatnya. Keanekaragaman itu tentu saja merupakan suatu pedoman dan faham yang cocok dengan karakter kemajemukan itu sendiri. Paham yang dirasakan cocok dengan kemajemukan ini adalah konsep kebangsaan yaitu nasionalisme.

Nasionalisme Bangsa Indonesia merupakan perwujudan rasa cinta Bangsa Indonesia terhadap Negara dan tanah air berdasarkan Pancasila. Nasionalisme yang dilandasi Pancasila menuntun untuk memiliki sikap menjunjung tinggi nilai kemanusiaan, tenggang rasa, dan merasa bahwa Bangsa Indonesia merupakan bagian dari seluruh umat manusia. Nasionalisme kini berada dalam pusaran peradapan baru bernama globalisasi dan kian mendapat tantangan yang begitu besar.

Globalisasi memiliki pengaruh yang sangat kuat dan memunculkan keberagaman baru. Globalisasi yang memunculkan keberagaman baru bagi Bangsa Indonesia, akan mempengaruhi nasionalisme dan patriotisme Bangsa Indonesia. Pengaruh negatif globalisasi terhadap nasionalisme salah satunya ialah masyarakat Indonesia khususnya kaum muda banyak yang menganggap bahwa nilai-nilai yang terdapat dalam nasionalisme dan patriotisme sudah tidak zaman lagi untuk dibicarakan dan dilaksanakan.

Sikap nasionalisme atau cinta tanah air ini harus dimiliki oleh setiap penduduk setiap Bangsa di dunia ini. Hal ini dikarenakan pentingnya sikap nasionalisme dalam menjaga keutuhan suatu Bangsa. Begitu pula halnya dengan Indonesia, setiap warganya harus memiliki sikap nasionalisme, sebagai salah satu cara untuk menjaga keutuhan Negara Kesatuan Republik Indonesia (NKRI). Peran serta pemuda khususnya pelajar sebagai generasi penerus sangatlah penting dalam menjaga keutuhan NKRI karena di pundak generasi muda masa depan Bangsa ini digantungkan. Mempertahankan dan membela negara merupakan tugas bagi setiap warga negara Indonesia tidak terkecuali para generasi muda khususnya pelajar sabagai generasi penerus yang ikut menentukan nasib Bangsa ini. Untuk mengemban tugas tersebut setiap warga negara perlu memiliki pemahaman dan jiwa nasionalisme sebagai dasarnya. Generasi muda dalam hal ini pelajar khususnya juga harus memiliki jiwa dan semangat nasionalisme yang membara di dalam dirinya.

Akan tetapi nasionalisme pelajar kini dirasa kurang dan mulai luntur terkikis seiring perkembangan zaman. Hal ini terlihat dari anak-anak lebih menyukai dan bangga dengan budaya asing dari pada budaya asli Bangsanya sendiri dan merasa bangga manakala menggunakan produk luar negeri, dibandingkan jika menggunakan produk Bangsa sendiri. Sedikitnya anak yang hafal dengan lagu kebangsaan Indonesia raya. Sedangkan kebanyakan 
anak lebih suka dengan lagu pop atau dangdut yang sering hadir di layar kaca. Anak cenderung kurang suka dengan kebudayaan Bangsa Indonesia karena mereka menganggap kebudayaan Indonesia adalah kebudayaan kuno atau tradisional, di lain sisi anak zaman sekarang lebih menyukai kebudayaan-kebudayaan asing yang masuk ke Bangsa ini. sehingga kebudayaan Indonesia perlahan-lahan menghilang dan akibatnya kebudayaan kita diklaim oleh negara lain seperti kesenian Reog Ponorogo, musik Angklung bahkan Batik.

Selain itu, lunturnya nilai-nilai nasionalisme pada anak-anak juga dapat dilihat dari kurangnya penghayatan siswa ketika mengikuti upacara bendera, banyak sekali siswa yang tidak hafal lagu-lagu nasional maupun lagu daerah, tidak mengetahui pahlawan-pahlawan nasional, bahkan juga banyak siswa yang tidak hafal sila-sila Pancasila. Dengan adanya kecenderungan sikap ketidakjujuran yang semakin membudaya, berkembangnya rasa tidak hormat kepada guru, orang tua, dan pemimpin, serta kurangnya sopan santun dikalangan siswa. Hal ini juga menunjukkan adanya kemerosotan rasa nasionalisme sebagai pijakan teguh kepribadian Bangsa telah hilang dan luntur seiring dengan perkembangan zaman.

Sebagai contoh yang tidak baik bagi kaum remaja adalah masih tingginya kasus korupsi yang dilakukan para elit negara. Sesuai data yang ditemukan oleh peneliti, berdasarkan laporan ICW (Indonesia Coruption Watch) terdapat peningkatan sebanyak 28 kasus korupsi, meski jumlah tersangka mengalami penurunan sebanyak 8 tersangka pada priode 2013-2014, dapat dilihat pada gambar dibawah ini:

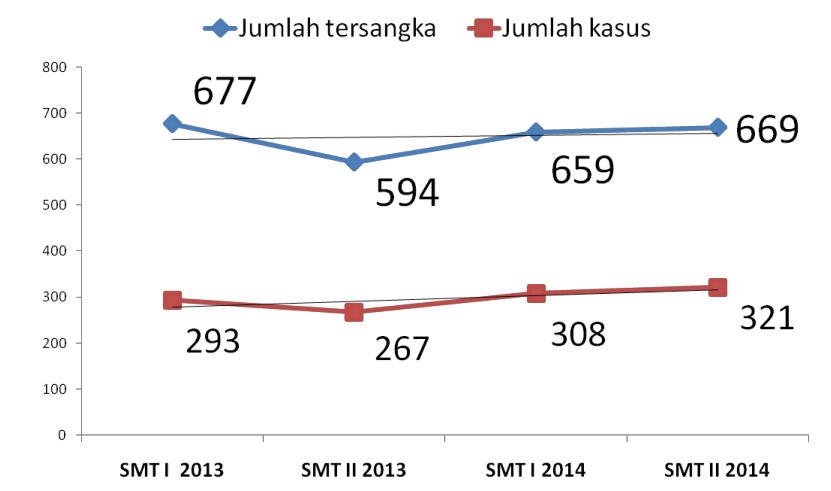

Sumber : www.antikorupsi.org (Diakses 20 Januari 2016)

\section{Gambar 1 Tingkat Korupsi di Indonesia}

\section{Keterangan:}

Tahun 2013 semester I jumlah tersangka 677 dan jumlah kasus 293

Tahun 2013 semester II jumlah tersangka 594 dan jumlah kasus 267

Tahun 2014 semester I jumlah tersangka 659 dan jumlah kasus 308

Tahun 2014 semester II jumlah tersangka 669 dan jumlah kasus 321 
Para elit Bangsa tidak lagi memikirkan kepentingan negara melainkan mementingkan kepentingan pribadi dan golongan. Yang memicu lunturnya moral dan rasa nasionalisme generasi muda adalah tidak ada rasa penyesalan bagi para pelaku korupsi atas tindakan yang dilakukan.

Selain kasus korupsi yang tejadi dikalangan elit pemerintahan fakta lain yang menunjukkan merosotnya rasa nasionalisme yaitu masih maraknya tawuran antar pelajar. Berdasarkan hasil penelusuran penulis, tahun 2013 sampai tahun 2014 terdapat peningkatan yaitu sebanyak 229 kasus tawuran dari pada tahun 2012 yang hanya 128 kasus (beritakaltara.com, diunduh pada 3 september 2015). Selain itu kasus terbaru yang didapatkan oleh penulis yaitu tewasnya siswa SMK PGRI 2 Kota Tangerang akibat tawuran (hariantanggerang.com, diunduh pada 3 september 2015). Terjadinya kasus tawuran tersebut mencerminkan rendahnya nilai-nilai nasionalisme dikalangan pelajar.

Oleh karena itu maka, sudah sangat mendesak untuk mewujudkan identitas nasional serta menanamkan nilai-nilai nasionalisme dan patriotisme sejak dini kepada siswa sebagai warga negara yang dapat dihandalkan bagi Bangsa dan negara di masa depan.

Berdasarkan uraian tersebut di atas bahwa nilai-nilai nasionalisme dan patriotisme mengalami penurunan dari tahun ketahun, karena kuranganya pemahaman kita akan pentingnya nasionalisme dan patriotisme. Salah satu upaya penanaman nilai-nilai nasionalisme dan patriotisme diantaranya melalui pendidikan formal. Jenjang pendidikan formal yang terdapat di Indonesia salah satunya adalah sekolah menengah atas (SMA). Pada jenjang pendidikan ini terdapat mata pelajaran PKn yang dapat menjadi sarana untuk menanamkan sikap dan moral yang baik kepada peserta didik. Selain itu, mata pelajaran ini banyak sekali mengajarkan nilai-nilai nasionalisme, patriotisme dan pengetahuan kewarganegaraan.

Mata pelajaran Pendidikan Kewarganegaraan merupakan salah satu mata pelajaran yang memfokuskan pada pembentukan diri yang beragam dari segi agama, sosial kultur, bahasa, usia dan suku Bangsa untuk menjadi warga negara Indonesia yang cerdas, terampil, dan berkarakter yang diamanatkan oleh Pancasila dan UUD 1945. Selain itu mata pelajaran ini merupakan mata pelajaran yang syarat akan pendidikan nilai-nilai, terutama nilai nasionalisme dan patriotisme yang menjadi tujuan pokok dari pembelajaran.

Pelaksanaan penanaman nilai nasionalisme dan patriotisme melalui pelajaran PKn yang dilakukan di SMA Negeri 1 Pundong Bantul yang terletak di Jalan Pundong Srihardono Pundong Bantul. Kondisi SMA Negeri 1 Pundong mempunyai potensi untuk mengembangkan pembiasaan yang ada di sekolah terkait dengan nilai-nilai nasionalisme, 
sehingga menarik bagi peneliti untuk memilih SMA Negeri 1 Pundong sebagai lokasi penelitian. Dengan demikian peneliti melakukan penelitian dengan judul Penanaman NilaiNilai Nasionalisme dan Patriotisme Melalui Materi Sikap Semangat Kebangsaan dan Patriotisme Dalam Kehidupan Bermasyarakat, Berbangsa dan Bernegara Pada Pembelajaran Pkn di SMA Negeri 1 Pundong Bantul.

\section{KAJIAN TEORI}

A. Pengertian Nilai

Dalam bukunya Louis O. Kattsof "Pengantar Filsafat" disebutkan bahwa nilai merupakan obyek keinginan, mempunyai kualitas yang dapat menyebabkan orang mengambil sikap "menyetujui”" atau mempunyai nilai sikap tertentu (Louis O Ktsof, 1986:332). Nilai juga diartikan hal-hal atau sifat-sifat yang bermanfaat atau penting untuk kemanusiaan (KBBI, 2005:1100).

Nilai itu ideal bersifat ide, yang dapat ditangkap indra adalah perbuatan yang mengandung nilai tersebut. Nilai tidak ada dengan sendirinya, seperti wujud suatu barang. Suatu barang tetap ada, sekalipun manusia tidak ada. Nilai itu tidak ada, kalau manusia tidak ada atau tidak melihatnya. Nilai itu baru timbul, ketika terjadi hubungan antara manusia sebagai subyek dan barang itu sebagai obyek. Nilai juga diartikan sebagai sesuatu yang berharga, berguna, indah, memperkaya batin, dan menyadarkan manusia akan harkat dan martabatnya. Nilai bersumber pada budi yang berfungsi mendorong dan mengarahkan sikap dan perilaku manusia (Syahrial Syarbaini, 2011:33).

Keyakinan manusia dan masyarakat terhadap nilai-nilai baik dan buruk tersebut dapat mempengaruhi pemikiran, perasaan dan tindakan manusia dalam berbagai aspek kehidupan yang kemudian menjadi contoh atau perbuatan selanjutnya. Jika perbuatan dinilai salah, sebagai contoh korupsi, maka manusia akan tergerak menghindari perbuatan tersebut. Selain itu, keyakinan tersebut juga dapat menyebabkan orang bersikap menyetujui atau tidak terhadap hal itu.

\section{B. Pengertian Nasionalisme dan Patriotisme}

Secara etimologi, "nasionalisme" berasal dari kata "nasional" dan "isme" yaitu paham kebangsaan yang mengandung makna kesadaran dan semangat cinta tanah air, memiliki kebanggaan sebagai Bangsa, atau memelihara kehormatan Bangsa, memiliki rasa solidaritas terhadap musibah dan kekurangberuntungan saudara setanah air, seBangsa dan senegara, persatuan dan kesatuan (Budiyanto, 2006: 31). 
Menurut Ensiklopedia Indonesia, nasionalisme adalah sikap politik dan sosial dari sekelompok Bangsa yang mempunyai kesamaan kebudayaan bahasa dan wilayah serta kesamaan cita-cita dan tujuan dengan meletakkan kesetiaan yang mendalam terhadap kelompok Bangsanya (Budiyanto, 2006: 31).

Patriotisme berasal dari kata dasar "patriot" yang dalam Kamus Besar Bahasa Indonesia diartikan sebagai pecinta (pembela) tanah air atau seorang pejuang sejati. Dalam kamus hukum tulisan Dr. Andi Hamzah, S.H. patriot diartikan sebagai pecinta tanah air, pejuang Bangsa (Suprapto dkk, 2007: 38).

Makna "patriotisme" yang berasal dari kata "patriot" dan "isme" yang merupakan sifat kepahlawanan atau jiwa pahlawan (Indonesia), atau "heroism" dan "patriotisme" dalam bahasa inggris adalah sikap yang gagah berani, pantang menyerah dan rela berkorban (harta, jiwa/raga) demi Bangsa dan negara. Sikap patriotisme merupakan sikap yang bersumber dari perasaan cinta pada tanah air sehingga menimbulkan kerelaan berkorban untuk Bangsa dan negaranya (Budiyanto, 2007: 32).

Penanaman merupakan proses, cara, perbuatan menanam, menanami, menanamkan (KBBI, 2002: 1134). Pada arti kata penaman tersebut yang penulis garis bawahi adalah kalimat perbuatan menanam, dalam KBBI (2002: 1134) juga dijelaskan bahwa arti ketiga dari kata menanam adalah menaburkan (paham, ajaran, dan sebagainya); memasukkan, membangkitkan, atau memelihara (perasaan, cinta kasih, semangat, dan sebagainya). Penanaman yang dimaksud dalam penelitian ini adalah proses memasukkan, membangkitkan atau memelihara nilai-nilai nasionalisme dan patriotisme dalam diri siswa.

\section{Pengertian Pendidikan Kewarganegaraan}

Pendidikan kewarganegaraan menurut Depdiknas (2003:2). Kewarganegaran (citizenship) merupakan mata pelajaan yang memfokuskan pada pembentukan diri yang beragam dari segi agama, sosio-kultural, bahasa, usia dan suku Bangsa untuk menjadi warga negara Indonesia yang cerdas, terampil, dan berkarakter yang diamanatkan oleh pancasila dan UUD 1945. Selain itu dalam pendidikan kewarganegaraan sudah menjadi pengetahuan dasar dan kemampuan dasar yang berkenaan dengan hubungan warga negara yang dapat diandalkan oleh Bangsa dan negara.

1. Pengertian mata pelajaran Pendidikan Kewarganegaraan dan tujuannya.

Mata pelajaran Pendidikan Kewarganegaraan merupakan mata pelajaran yang memfokuskan pada pembentukan warganegara yang memahami dan mampu melaksanakan hak-hak dan kewajibannya untuk menjadi warga negara Indonesia yang 
cerdas, terampil, dan berkarakter yang diamanatkan oleh Pancasila dan UUD 1945 (Depdiknas, 2006:64).

Mata pelajaran Pendidikan Kewarganegaraan bertujuan agar peserta didik memiliki kemampuan sebagai berikut :

a) Berpikir secara kritis, rasional, dan kreatif dalam menghadapi isu kewarganegaraan.

b) Berpartisipasi secara aktif dan bertanggungjawab, dan bertindak secara cerdas dalam kegiatan bermasyarakat, berbangsa, dan bernegara, serta anti korupsi.

c) Berkembang secara positif dan demokratis untuk membentuk diri berdasarkan karakter-karakter masyarakat Indonesia agar dapat hidup bersama dengan BangsaBangsa lainnya.

d) Berinteraksi dengan Bangsa-Bangsa lain dalam percaturan dunia secara langsung atau tidak langsung dengan memanfaatkan teknologi informasi dan komunikasi (BNSP, 2006:78).

2. Ruang Lingkup Pendidikan Kewarganegaraan

Ruang lingkup mata pelajaran Pendidikan Kewarganegaraan meliputi aspek-aspek sebagai berikut:

a) Persatuan dan Kesatuan Bangsa, meliputi : hidup rukun dalam perbedaan, cinta lingkungan, kebanggaan, sebagai Bangsa Indonesia, sumpah pemuda, keutuhan Negara Kesatuan Republik Indonesia, partisipasi dalam pembelaan negara, sikap positif terhadap Negara Kesatuan Republik Indonesia, keterbukaan dan jaminan keadilan,

b) Norma, hukum, dan peraturan, meliputi : tertib dalam kehidupan keluarga, tata tertib di sekolah, norma yang berlaku di masyarakat, peraturan-peraturan daerah, normanorma dalam kehidupan berbangsa dan bernegara, sistem hukum, dan peradilan nasional, hukum, dan peradilan internasional.

c) Hak asasi manusia meliputi: hak dan kewajiban anak, hak dan kewajiban anggota masyarakat, instrumen nasional dan internasional HAM, pemajuan, penghormatan, dan perlindungan.

d) Kebutuhan warga negara meliputi: hidup gotong royong, harga diri sebagai warga masyarakat, kebebasan berorganisasi, kemerdekaan mengeluarkan pendapat, menghargai keputusan bersama, prestasi diri, persamaan kedudukan warga negara. 
e) Konstitusi Negara meliputi: proklamasi kemerdekaan dan konstitusi yang pertama, konstitusi-konstitusi yang pernah digunakan di Indonesia, hubungan dasar negara dengan konstitusi.

f) Kekuasaan dan politik, meliputi: pemerintah desa dan kecamatan, pemerintahan daerah dan otonomi, pemerintah pusat, demokrasi dan sistem politik, budaya demokrasi menuju masyarakat madani, sistem pemerintahan, pers dalam masyarakat demokrasi.

g) Pancasila, meliputi: kedudukan pancasila sebagai dasar negara, pengalaman nilainilai pancasila dalam kehidupan sehari-hari, pancasila sebagai ideologi terbuka.

h) Globalisasi meliputi: globalisasi di lingkungannya, politik luar negeri Indonesia di era globalisasi, dampak globalisasi, hubungan internasional dan organisasi internasional, dan mengevaluasi globalisasi (http://bsnp-indonesia.org/id/ Diakses 5 September 2015).

3. Standar Kompetensi dan Kompetensi Dasar

Satuan Pendidikan $\quad$ : Sekolah Menengah Atas (SMA)

Mata Pelajaran : Pendidikan Kewarganegaraan

Berikut beberapa standar kompetensi dan kompetensi dasar yang mencakup dalam materi pendidikan Kewarganegaraan.

Tabel 2 Standar Kompetensi dan Kompetensi Dasar

\begin{tabular}{|c|c|}
\hline \multicolumn{2}{|c|}{ Kelas X, Semester 1} \\
\hline Standar Kompetensi & Kompetensi Dasar \\
\hline $\begin{array}{l}\text { 1. Memahami hakikat } \\
\text { Bangsa dan Negara } \\
\text { Kesatuan Republik } \\
\text { Indonesia (NKRI) }\end{array}$ & $\begin{array}{l}\text { 1.1 Mendeskripsikan hakikat Bangsa dan } \\
\text { unsur-unsur terbentuknya negara } \\
\text { 1.2 Mendeskripsikan hakikat negara dan } \\
\text { bentuk-bentuk kenegaraan } \\
\text { 1.3 Menjelaskan pengertian, fungsi dan } \\
\text { tujuan NKRI } \\
\text { 1.4 Menunjukkan semangat kebangsaan, } \\
\text { nasionalisme dan patriotisme dalam } \\
\text { kehidupan bermasyarakat, berbangsa } \\
\text { dan bernegara }\end{array}$ \\
\hline
\end{tabular}




\begin{tabular}{|l|l|}
\hline $\begin{array}{l}\text { 2. Menampilkan sikap } \\
\text { positif terhadap sistem } \\
\text { hukum dan peradilan } \\
\text { nasional }\end{array}$ & $\begin{array}{c}\text { 2.1 Mendeskripsikan pengertian sistem } \\
\text { hukum dan peradilan nasional } \\
\text { 2.2 Menganalisis peranan lembaga- } \\
\text { lembaga peradilan } \\
\text { 2.3 Menunjukkan sikap yang sesuai dengan } \\
\text { ketentuan hukum yang berlaku } \\
\text { 2.4 Menganalisis upaya pemberantasan } \\
\text { korupsi di Indonesia } \\
\text { 2.5 Menampilkan peran serta dalam upaya } \\
\text { pemberantasan korupsi di Indonesia }\end{array}$ \\
$\begin{array}{l}\text { 3. Menampilkan peran } \\
\text { serta dalam upaya } \\
\text { pemajuan, } \\
\text { penghormatan dan } \\
\text { perlindungan Hak Asasi } \\
\text { Manusia (HAM) }\end{array}$ & $\begin{array}{c}\text { 2.6 Menganalisis upaya pemajuan, } \\
\text { penghormatan, dan penegakan HAM } \\
\text { 2.7 Menampilkan peran serta dalam upaya } \\
\text { pemajuan, penghormatan, dan } \\
\text { penegakan HAM di Indonesia } \\
\text { 2.8 Mendeskripsikan instrumen hukum dan } \\
\text { peradilan internasional HAM }\end{array}$ \\
\hline
\end{tabular}

\begin{tabular}{|c|c|}
\hline \multicolumn{2}{|r|}{ Kelas X, Semester 2} \\
\hline Standar Kompetensi & Kompetensi Dasar \\
\hline $\begin{array}{l}\text { 4. Menganalisis hubungan } \\
\text { dasar negara dengan } \\
\text { konstitusi }\end{array}$ & $\begin{array}{l}\text { 4.1 Mendeskripsikan hubungan dasar } \\
\text { negara dengan konstitusi } \\
\text { 4.2 Menganalisis substansi konstitusi } \\
\text { negara } \\
\text { 4.3 Menganalisis kedudukan pembukaan } \\
\text { UUD } 1945 \text { Negara Kesatuan Republik } \\
\text { Indonesia } \\
\text { 4.4 Menunjukkan sikap positif terhadap } \\
\text { konstitusi negara }\end{array}$ \\
\hline $\begin{array}{l}\text { 5. Menghargai persamaan } \\
\text { kedudukan warga } \\
\text { negara dalam berbagai } \\
\text { aspek kehidupan }\end{array}$ & $\begin{array}{l}\text { 5.1 Mendeskripsikan kedudukan warga } \\
\text { negara dan pewarganegaraan di } \\
\text { Indonesia } \\
\text { 5.2 Menganalisis persamaan kedudukan } \\
\text { warga negara dalam kehidupan } \\
\text { bermasyarakat, berbangsa dan negara } \\
\text { 5.3 Menghargai persamaan kedudukan } \\
\text { warga negara tanpa membedakan ras, } \\
\text { agama, gender, golongan, budaya, dan } \\
\text { suku }\end{array}$ \\
\hline $\begin{array}{l}\text { 6. Menganalisis sistem } \\
\text { politik di Indonesia }\end{array}$ & $\begin{array}{l}\text { 6.1 Mendeskripsikan supra struktur dan } \\
\text { infra struktur politik di Indonesia } \\
\text { 6.2 Mendeskripsikan perbedaan sistem } \\
\text { politik di berbagai negara } \\
\text { 6.3 Menampilkan peran serta dalam sistem } \\
\text { politik di Indonesia }\end{array}$ \\
\hline
\end{tabular}

Sumber: http://bsnp-indonesia.org/id//Diakses 5 September 2015) 


\section{Metode Pembelajaran Kewarganegaraan}

Metode pembelajaran dalam Pendidikan Kewarganegaraan orientasinya bukanlah penyajian pengetahuan saja, akan tetapi ditujukan kepada rangsangan atau stimulus kondisi, sehingga terjadi perubahan sikap dan perbuatan siswa menurut tuntutan moral Pancasila. Metode pembelajaran dalam pendidikan nilai menurut Soenarjati dan Cholisin, adalah suatu cara yang dilakukan oleh guru secara sadar, teratur, dan bertujuan untuk menyampaikan bahan materinya, maka proses penyampaiannya itu diharapkan terjadi perubahan sikap dan perbuatan siswa sesuai dengan tujuan yang ditentukan dalam kurikulum (Soenarjati dan Cholisin ,1994: 117).

Soenarjati dan Cholisin (1994: 131) menguraikan metode pembelajaran beraneka ragam sebagai berikut:

a. Metode ceramah, yaitu bagaimana cara penyajian dan penyampaian materi pelajaran dari guru kepada siswa secara lisan untuk mencapai tujuan pengajaran.

b. Metode tanya-jawab, yaitu cara untuk menyampaikan atau menyajikan bahan pelajaran dalam bentuk pertanyaan dari guru dan harus dijawab oleh murid.

c. Metode diskusi, yaitu cara penyajian bahan pelajaran dengan menugaskan pelajaran atau kelompok pelajar melaksanakan percakapan ilmiah untuk mencari kebenaran dalam rangka mewujudkan tujuan pelajaran yang di dalamnya selalu ada persoalan yang dibahas, di aanalisis dan disimpulkan.

d. Metode pemecahan masalah (Problem Solving), yaitu cara mengajar yang memberikan kesempatan pada semua siswa untuk menganalisa dan melakukan sintesa dalam kesatuan struktur atau situasi di mana masalah itu berada atas inisiatif sendiri.

e. Metode inquiri (istilah inquiri, discovery, dan problem solving mengandung arti sejiwa), yaitu menunjukkan suatu kegiatan atau cara belajar yang bersifat logis-kritis-analisis menuju suatu kesimpulan yang meyakinkan.

f. Metode VCT (Value Clarification Techique), yaitu metode sebagai upaya membina nilainilai yang diyakini, sehubungan dengan timbulnya kekaburan nilai atau konflik nilai ditengah-tengah kehidupan masyarakat.

g. Metode bermain peran (roller playing), yaitu cara yang ditetapkan dalam proses belajar mengajar di mana siswa diberikan kesempatan untuk melaksanakan kegiatan-kegiatan untuk menjelaskan, sikap, dan nilai-nilai serta memainkan tingkah laku (peranan) tertentu sebagaimana yang terjadi dalam kehidupan masyarakat. 
h. Metode karya wisata, yaitu kunjungan ke suatu tempat di mana peserta akan menyumbangkan tenaganya kepada obyek yang dikunjungi yang biasanya sebagai penerapan teori-teori tertentu yang telah dipelajari.

i. Metode simulasi, yaitu metode permainan di mana para pemain dimasukkan dalam simulasi, sehingga mereka berada dalam situasi yang sesungguhnya.

E. Materi Sikap Semangat Kebangsaan dan Patriotisme Dalam Kehidupan Bermasyarakat, Berbangsa dan Bernegara

Dalam menentukan materi pembelajaran yang akan disampaikan di kelas berpedoman terhadap silabus yang telah ditentukan terlebih dahulu. Silabus adalah rencana pembelajaran pada suatu kelompok mata pelajaran atau tema tertentu yang mencakup standar kompetensi, kompetensi dasar, materi pokok atau pembelajaran, kegiatan pembelajaran, indikator, penilaian, alokasi waktu, dan sumber atau bahan atau alat belajar (BSNP, 2006:14). Silabus merupakan penjabaran standar kompetensi dan kompetensi dasar ke dalam materi pokok atau pembelajaran, kegiatan pembelajaran, dan indikator pencapaian kompetensi untuk penilaian.

Menurut Kemdikbud RPP adalah rencana pembelajaran yang dikembangkan secara rinci dari suatu materi pokok atau tema tertentu yang mengacu pada silabus. Rencana kegiatan pembelajaran tatap muka untuk satu pertemuan atau lebih dikembangkan secara rinci dari suatu materi pokok atau tema tertentu yang mengacu pada silabus untuk mengarahkan kegiatan pembelajaran siswa dalam upaya mencapai Kompetensi Dasar (KD). RPP merupakan persiapan yang harus dilakukan guru sebelum mengajar. Persiapan disini dapat diartikan persiapan tertulis maupun persiapan mental, situasi emosional yang ingin dibangun, lingkungan belajar yang produktif, termasuk meyakinkan pembelajar untuk mau terlibat secara penuh. Rencana Pelaksanaan Pembelajaran dengan silabus mempunyai perbedaan, meskipun dalam hal tertentu mempunyai persamaan.

Materi Sikap Semangat Kebangsaan dan Patriotisme Dalam Kehidupan Bermasyarakat, Berbangsa dan Bernegara:

Nasionalisme adalah satu paham yang menciptakan dan mempertahankan kedaulatan sebuah negara (dalam bahasa inggris “nation”) dengan mewujudkan satu konsep identitas bersama untuk sekelompok manusia. Nasionalisme adalah faham kebangsaan yang tumbuh karena:

- Adanya persamaan nasib dan sejarah serta kepentingan untuk hidup bersama

- Sebagai suatu Bangsa yang merdeka, bersatu, berdaulat, demokratis, dan maju di dalam suatu kesatuan Bangsa dan negara, serta 
- Cita-cita bersama guna mencapai, memelihara, dan mengandikan identitas, persatuan, kemakmuran, dan kekuatan atau kekuasaan negara Bangsa yang bersangkutan.

Nasionalisme:

a. Dalam arti sempit, yaitu perasaan kebangsaan atau cinta terhadap Bangsanya yang tinggi atau berlebih-lebihan, sehingga memandang Bangsa lain lebih rendah (chauvinisme)

b. Dalam arti luas, yaitu perasaan cinta atau bangga terhadap tanah air dan Bangsanya sendiri dengan tetap menghormati Bangsa lain karena merasa sebagai bagian dari Bangsa lain di dunia

Manifestasi faham nasionalisme berupa:

a. Kesadaran seseorang bahwa dirinya merupakan anggota atau warga negara dan Bangsanya

b. Kebanggan seseorang akan negara dan Bangsanya

c. Kecintaan seseorang akan negara dan Bangsanya

d. Kesetiaan dan ketaatan seseorang terhadap negara dan Bangsanya

e. perjuangan seseorang bagi kepentingan negara dan Bangsanya

f.kerelaan berkorban bagi negara dan Bangsanya

Patriotisme adalah sikap yang berani, pantang menyerah dan rela berkorban demi Bangsa dan negara. Patriotisme berasal dari kata "patriot" dan "isme" yang berarti sifat kepahlawanan atau jiwa pahlawan, atau "heroism" dan "patriotisme" dalam bahasa inggris. Pengorbanan ini dapat berupa pengorbanan harta benda maupun jiwa raga.

\section{a. Sikap Kepahlawanan dalam Kehidupan Sehari-hari}

Yang disebut pahlawan bukan hanya orang-orang yang berjuang melawan penjajah tetapi setiap orang yang berjasa kepada Bangsa ataupun kepada orang lain bisa disebut pahlawan. Orang tua berjasa kepada kita karena telah melahirkan, merawat dan mendidik kita. Petani berjasa dalam menyediakan kebutuhan pangan. Guru berjasa dalam mengajarkan ilmu pengetahuan. Semua orang dapat berjasa dan menjadi pahlawan bagi Bangsa ini sesuai dengan caranya masing-masing.

Sikap kepahlawanan sangat penting dan harus dimiliki setiap orang. Sejak dini sikap kepahlawanan harus mulai dipupuk dan dibiasakan. Orang yang tidak memiliki sikap kepahlawanan akan menjadi penakut, pelit atau tidak mau berkorban, malas berusaha, egois (mementingkan diri sendiri) dan mudah putus asa. Walaupun tidak mendapat penghargaan dari siapapun sikap kepahlawanan harus senantiasa dipupuk sebab penghargaan bukanlah tujuan dari seorang pahlawan. Kita harus membiasakan diri 
memiliki sikap kepahlawan dalam kehidupan sehari-hari. Sikap kepahlawan dapat kita terapkan di lingkungan keluarga, lingkungan sekolah dan di lingkungan masyarakat. Berikut ini adalah contoh sikap kepahlawanan dalam kehidupan seharihari:

1) Lingkungan keluarga

Di lingkungan keluarga kita dapat menerapkan sikap kepahlawan dengan saling menolong dengan ikhlas. Biasanya di rumah telah ditetapkan aturan dan tugas-tugas rumah. Misalnya ayah mencuci motor, ibu memasak, kamu mencuci piring dan adikmu menyapu rumah. Jika suatu saat adikmu tidak dapat melaksanakan tugas karena sakit, maka kamu harus siap menggantikan tugasnya dengan rela dan tulus ikhlas.

2) Lingkungan sekolah

Di lingkungan sekolah kita pun dapat mewujudkan sikap kepahlawan. Misalnya jika ada teman yang tertimpa musibah, seluruh siswa di kelas dengan suka rela mengumpulkan bantuan dana dan barang. Sikap kepahlawanan di sekolah juga bisa diwujudkan dengan berani mengakui kesalahan, jika memang berbuat salah.

3) Lingkungan masyarakat

Lingkungan masyarakat merupakan lingkungan yang lebih luas. Sikap kepahlawanan dapat diwujudkan misalnya dengan ikut serta bekerja bakti membersihkan lingkungan. Jika memiliki suatu makanan tidak lupa memberikan kepada tetangga. Jika ada suatu daerah yang tertimpa musibah, kita bantu sesuai dengan kemampuan kita. Ini juga merupakan sikap kepahlawanan.

Selain memiliki sikap kepahlawanan para pejuang Bangsa kita juga memiliki sikap patriotisme. Apa yang dimaksud dengan patriotisme? Patriotisme artinya cinta tanah air. Para pahlawan pendahulu kita berjuang mengusir penjajah tentunya didasari oleh rasa cinta tanah air. Mereka tidak rela Bangsanya diinjak-injak oleh para penjajah. Sikap patriotisme tidak hanya dimiliki oleh para pahlawan Bangsa. Sebagai warga negara yang baik kita pun harus memiliki sikap patriotisme. Siapa lagi yang mencintai Bangsa ini kalau bukan kita, warga negara Indonesia? Perjuangan kita saat ini sudah bukanlah perjuangan melawan para penjajah. Setelah merdeka, justru tantangan semakin besar. Kita saat ini mesti berjuang melawan kemiskinan, kebodohan dan keterbelakangan. 
Sikap patriotisme dapat diwujudkan dalam banyak hal. Wujud sikap patriotisme antara lain sebagai berikut:

1) Mencintai dan menggunakan produk dalam negeri

Mencintai dan menggunakan produk-produk dalam negeri merupakan bagian dari cinta tanah air. Dengan menggunakan produk dalam negeri berarti kita memberi keuntungan kepada warga Indonesia sendiri. Baik pembuatnya ataupun pedagangnya. Berarti juga memberi keuntungan kepada negara. Sebenarnya produk-produk dalam negeri tak takkalah dengan produk luar negeri. Bahkan banyak produk-produk asli buatan Indonesia yang ditiru orang luar negeri.

2) Tidak merusak lingkungan hidup

Lingkungan hidup haruslah dijaga kelestariannya. Merusaknya berarti kita tidak mencintai tanah air. Lingkungan hidup yang rusak akan merugikan manusia sendiri.

3) Ikut serta memelihara fasilitas umum

Fasilitas umum merupakan sarana yang disediakan oleh pemerintah untuk kebutuhan masyarakat. Contohnya adalah telepon umum, jembatan, halte, kereta api dan lain-lainnya. Jika kita merusak fasilitas umum akan merugikan orang lain dan negara. Kita sendiri juga tidak dapat menggunakannya lagi.

4) Ikut serta dalam pembangunan Bangsa

Negara kita harus terus membangun agar lebih maju dan kehidupan rakyatnya lebih baik. Bila kita ingin mencintai tanah air, maka kita harus ikut serta dalam pembangunan. Ikut serta dalam pembangunan bisa diwujudkan dengan taat membayar pajak, menjadi pegawai yang baik, dan sebagainya.

5) Mentaati peraturan yang ada

Peraturan dibuat agar masyarakat tertib dan nyaman. Jika kita melanggar peraturan akan merugikan diri kita sendiri. Bahkan orang lain dan negara juga akan dirugikan. Berarti jika kita melanggar peraturan berarti kita tidak cinta tanah air.

6) Melestarikan budaya Bangsa

Budaya Bangsa merupakan kekayaan Bangsa. Menjaga keles-tarian budaya Bangsa berarti mencintai Bangsa dan tanah air. Kita harus bangga memiliki budaya Bangsa yang beragam dan unik. Orang asing saja banyak yang mengagumi budaya Bangsa kita. Termasuk melestarikan budaya Bangsa adalah berbahasa Indonesia dengan baik dan benar.

Contoh:sikap patriotisme dalam kehidupan sehari-hari sangatlah banyak, sebagai siswa dapat menunjukkan sikap patriotisme dengan cara belajar yang rajin. Sebab dengan belajar rajinberarti sudah ikut serta dalam perjuangan memberantas kebidohan dan 
keterbelakangan. Kemampuan dapat mewujudkan sikap patriotisme dengan tidak membuang sampah di sembarang tempat.

\section{b. Sikap Positif Terhadap Pahlawan Bangsa}

Jasa para pahlawan Bangsa bagi Bangsa kita sangatlah besar. Mereka telah berjuang sepenuh jiwa raga untuk Bangsa kita. Banyak di antara mereka yang gugur pada saat berjuang membela Bangsa. Cita-cita mereka hanya satu, yakni terbebas dari belenggu penjajah. Mereka tidak sedikitpun mengharapkan imbalan. Oleh karena itu jasa para pahlawan Bangsa kita haruslah kita hargai dengan jiwa besar. Bangsa yang besar adalah Bangsa yang menghargai jasa para pahlawannya. Bagaimana cara kita menghargai jasa para pahlawan Bangsa kita?

Berikut ini adalah beberapa contoh cara menghargai jasa pahlawan Bangsa:

1) Mengabadikan foto dan nama pahlawan pada mata uang, nama jalan, bandara dan rumah sakit

2) Membuatkan monumen suatu peristiwa penting atau patung pahlawan.

3) Memberikan gelar dan tanda jasa

4) Mengisi kemerdekaan dengan pembangunan dan hal-hal yang positif

5) Meneladani sikap dan perjuangan para pahlawan

6) Mendoakan arwah para pahlawan agar diterima di sisi Tuhan

Di antara cara menghargai jasa para pahlawan Bangsa, yang paling penting adalah meneladani sikap dan perjuangannya. Jasa para pahlawan memang harus dikenang. Namun dikenang saja tidaklah cukup. Karena perjuangan belumlah selesai. Para pahlawan Bangsa yang telah gugur tentu akan bangga bila perjuangan mereka diteruskan oleh generasi saat ini. Agar dapat meneruskan perjuangan mereka, kita pun harus meneladani sikap kepahlawanan dan patriotisme mereka dalam kehidupan sehari-hari.

\section{METODE}

\section{A. Jenis Penelitian}

Jenis penelitian ini merupakan jenis penelitian berdasarkan pendekatan kualitatif. Penelitian kualitatif adalah penelitian untuk menjawab permasalahan yang memerlukan pemahaman secara mendalam dalam konteks waktu dan situasi yang bersangkutan, dilakuan secara wajar dan alami sesuai dengan kondisi objektif di lapangan tanpa adanya manipulasi, serta jenis data yang dikumpulkan terutama data kualitatif (Zainal Arifin, 2012: 29). 
Penelitian ini dilakukakan dengan cara pengamatan secara mendalam terhadap objek yang diteliti. Dalam penelitian ini seorang peneliti harus terjun langsung kelapangan.

Berdasarkan jenis metode, penelitian ini termasuk metode penelitian deskriptif yaitu penelitian yang digunakan untuk menggambarkan, menjelaskan dan menjawab tentang persoalan-persoalan, fenomena-fenomena dan peristiwa yang terjadi saat ini, baik fenomena sebagaimana adanya maupun analisis hubungan antara berbagai variabel dalam suatu hubungan (Zainal Arifin, 2012: 41).

B. Subjek Penelitian

Untuk mendapatkan data yang akurat dan valid maka subjek penelitian ini sangat penting. Subjek penelitian merupakan sumber dari data yang akan didapatkan sehingga subjek penelitian harus tepat.

Pada penelitian ini yang menjadi subyek penelitian adalah Kepala Sekolah SMA Negeri 1 Pundong, Guru mata pelajaran PKn, dan Siswa kelas X SMA Negeri 1 Pundong.

C. Tempat dan Waktu Penelitian

Penelitian ini dilaksanakan di SMA Negeri 1 Pundong di kabupaten Bantul kecamatan Pundong Yogyakarta, pada bulan Februari-Mei 2016

D. Variabel Penelitian

Tabel 3 Kisi-kisi variabel penelitian

\begin{tabular}{|c|c|c|}
\hline Variabel & Sub Variabel & Indikator \\
\hline \multirow{13}{*}{$\begin{array}{l}\text { Penanaman nilai-nilai } \\
\text { nasionalisme dan } \\
\text { patriotisme pada materi } \\
\text { sikap semangat } \\
\text { kebangsaan dan } \\
\text { patriotisme dalam } \\
\text { kehidupan bermasyarakat, } \\
\text { berbangsa, dan bernegara } \\
\text { pada pembelajaran Pkn di } \\
\text { SMA Negeri } 1 \text { Pundong }\end{array}$} & \multirow[t]{3}{*}{ 1. Penanaman } & Pelaksanaan \\
\hline & & Materi \\
\hline & & Metode \\
\hline & \multirow[t]{6}{*}{ 2. Nasionalisme } & $\begin{array}{l}\text { Cinta Bangsa dan } \\
\text { negara }\end{array}$ \\
\hline & & Toleransi \\
\hline & & Bertanggung jawab \\
\hline & & Kerja keras \\
\hline & & Disiplin \\
\hline & & Peduli sosial \\
\hline & \multirow[t]{4}{*}{ 3. Patriotisme } & Cinta tanah air \\
\hline & & Rela berkorban \\
\hline & & Kesetiaan \\
\hline & & Keberanian \\
\hline
\end{tabular}

Sumber: Peneliti 
E. Teknik Pengumpulan Data

Adapun teknik pengumpulan data yang digunakan peneliti adalah sebagai berikut:

1. Observasi

Teknik ini digunakan dengan cara peneliti mengadakan pengamatan langsung dilapangan terhadap gejala-gejala yang diselidiki. Metode ini merupakan pencatatan dan pengamatan secara sistematis terhadap fenomena-fenomena yang ada ditempat penelitian. Metode ini dilakukan untuk mendapatkan data yang bersifat fisik yang tidak dapat diperoleh denga cara interview. Data-data tersebut antara lain berupa sarana dan prasana yang dimiliki SMA Negeri 1 Pundong.

2. Wawancara

Dalam penelitian ini tanya jawab dilakukan kepada Kepala Sekolah SMA Negeri 1 Pundong, Guru mata pelajaran PKn, dan Siswa kelas X SMA Negeri 1 Pundong

3. Dokumentasi

Hasil penelitian dari wawancara dan observasi akan lebih kredibel atau dapat dipercaya jika didukung dengan dokementasi dari masa silam. Akan tetapi yang harus menjadi catatan adalah tidak semua dokumentasi memiliki kredibilitas yang tinggi sebagai penunjang data. Oleh karena itu peneliti harus cermat dalam memilah dan memilih dokumentasi-dokumentasi yang bisa dijadikan sebagai penunjang dari penelitian yang dilakukan. Data dokumentasi yang peneliti ambil dalam penelitian ini antara lain RPP dan silabus mata pelajaran PKN

\section{F. Teknik Analisis Data}

Analisa data dalam sebuah penelitian merupakan kegiatan sangat penting yang membutuhkan ketelitian dan kehati-hatian terhadap data yang telah dihasilkan. Melalui analisa data ini, data yang terkumpul berbentuk data mentah kemudian diolah sehingga menjadi data matang.

Teknik analisis data dilakukan dengan menggunakan analisa deskriptif kualitatif, dimana data-data yang telah diperoleh dari penelitian yang dilakukan kemudian digambarkan melalui kata-kata atau kalimat secara benar dan jelas.

Adapun langkah-langkah analisa data yang digunakan adalah sebagai berikut :

1. Reduksi data

Yaitu proses pemilahan, pemusatan perhatian pada penyederhanaan, pengabstrakan dan transformasi data kasar yang muncul dari catatan-catatan tertulis dilapangan. Pada tahap ini peneliti memilih data mana yang relevan dan kurang relevan dengan tujuan dan 
masalah penelitian, kemudian meringkas memberi kode, selanjutnya mengelompokkan sesuai dengan tema-tema yang ada (Zainal Arifin, 2012:172).

2. Display data (penyajian data)

Setelah data direduksi, maka langkah selanjutnya adalah penyajian data. Dalam penelitian kualitatif bisa dilakukan dalam bentuk uraian singkat, bagan, hubungan antar kategori dan sejenisnya. Akan tetapi yang paling sering dalam penelitian kualitatif data yang disajikan dalam bentuk teks naratif. Dengan demikian peneliti dapat lebih menguasai data yang diperoleh.

\section{Pengambilan kesimpulan dan verifikasi}

Dari data yang sudah diperoleh tersebut dicari maknanya degan cara mencari pola, model, tema, hubungan, persamaan, hal-hal yang sering muncul, dan sebagainya. Dari data tersebut peneliti mencoba mencari kesimpulan. Sedang verifikasi dapat dilakukan dengan cara mempelajari kembali data-data yang ada. Disamping itu juga dapat melakukan verifikasi dengan meminta pertimbangan dari pihak-pihak yang berhubungan dengan penelitian tersebut, seperti guru dan Kepala Sekolah.

\section{PEMBAHASAN}

1. Pelaksanaan Penanaman Nilai Nasionalisme dan Patriotisme

Kemerdekaan Bangsa Indonesia pada hakikat dan faktanya bukan merupakan hadiah atau pemberian dari penjajah. Indonesia merdeka atas dasar perjuangan rakyat. Rakyat Indonesia melakukan perlawanan dan perjuangan untuk merebut kemerdekaan dari tangan penjajah.

Rasa nasionalisme dan patriotisme yang tinggi adalah modal utama perjuangan Bangsa Indonesia untuk menyongsong kemerdekaan. Nasionalisme sebagai dasar perjuangan rakyat Indonesia melawan penjajahan yang telah menguasai Bangsa selama tiga setengah abad lamanya. Rasa nasionalisme yang tinggi dan dibarengi jiwa patriotisme yang besar membuat Bangsa Indonesia tidak takut untuk melawan dan mengusir para penjajah dari bumi pertiwi ini.

Setelah Bangsa Indonesia merdeka, nilai-nilai nasionalisme dan patriotisme tetap penting untuk dimiliki setiap warga negara, karena rasa cinta terhadap Bangsa dan negara menjadi modal utama generasi penerus Bangsa untuk membangun negeri. Hal itu sesuai dengan hasil wawancara yang dilakukan peneliti:

Menurut saya nilai cinta terhadap tanah air. Dengan adanya nilai nasionalisme pada diri setiap siswa maka itu sebagai modal utama untuk membangun negeri ini sebagai 
Bangsa yang lebih maju dan siap bersaing degan Bangsa lain di kanca internasional (Sartono, Kepala Sekolah: 1 Maret 2016).

Nasionalisme adalah suatu paham untuk mencintai Bangsa dan negara dengan kesadaran warga negaranya yang secara bersama-sama mencapai, mempertahankan, dan mengabdikan identitas, integritas, kemakmuran, dan kekuatan Bangsa (Sumarni, Guru: Selasa, 1 Maret 2016).

Selain rasa cinta terhadap negara, perjuangan yang dilaksanakan harus dibarengi dengan jiwa rela berkorban. rasa cinta terhadapa Bangsa dan negara tidak cukup menjadi modal untuk membangun negara sebagai Bangsa yang maju dan dapat bersaing dengan Bangsa lain. Sehingga dalam rangka membangun Bangsa selain nilai nasionalisme juga harus dibarengi dengan nilai patriotisme. Makna dari nilai patriotisme sesuai dengan hasil wawancara:

"Merupakan nilai rela berkorban demi kemajuan Bangsa dan negara. Sebenarnya antara nilai nasonalisme dan patriotisme tidak bisa dipisahkan antara satu dengan yang lain karena menurut saya untuk dapat rela berkorban bagi nusa dan Bangsa maka disetiap diri warga negara harus mempunyai rasa cinta terhadap Bangsanya itu sendiri (Sartono, Kepala Sekolah: 1 Maret 2016).

Sebenarnya antara nilai patriotisme dan nasionalisme hampir sama yaitu nilai cinta terhadap Bangsa dan negara akan tetapi untuk nilai patriotisme dibarengi dengan nilai kesetiaan dan rela berkorban tehadap Bangsa dan negara" (Mujito, Guru: Selasa, 1 Maret 2016).

Pada era modern yang ditandai dengan proses globalisasi seperti saat ini merupakan tantangan yang sangat besar bagi penerus Bangsa agar tetap bangga dan berjuang membela Bangsa dan negara di mata dunia. Oleh karena itu seperti hasil wawancara di atas maka pantaslah bahwa nilai nasionalisme dan patriotisme harus dimiliki setiap generasi penerus Bangsa sebagai modal membangun dan bersaing di kanca internasional.

Dalam proses pembelajaran PKn pada materi sikap semangat kebangsaan, nasionalisme dan patriotisme dalam kehidupan bermasyarakat, berbangsa dan bernegara. Siswa diajarkan nilai-nilai nasionalisme dan patriotisme yang harus dimiliki warga negara.

"Pada kegiatan pembelajaran dengan materi sikap semangat kebangsaan nasionalisme dan patriotisme dalam kehidupan berbangsa dan bernegara lebih menonjolkan penanaman nilai cinta tanah air, toleransi, bertanggung jawab, disiplin, rela berkorban, kesetiaan dan keberanian” (Mujito, Guru: Selasa, 1 Maret 2016).

Dalam proses pembelajaran kita mencoba untuk menanamkan seluruh nilai nasionalisme dan patriotisme antara lain : toleransi, cinta terhadap Bangsa dan negara, 
bertanggung jawab disiplin, rela berkorban dan lain-lain (Sumarni, Guru: Selasa, 1 Maret 2016)

Dalam proses pembelajaran selain menggunakan berbagai metode pembelajaran guru juga memberikan contoh-contoh yng mencerminkan sikap dan prilaku nasionalisme dan patriotisme. Hal ini sesuai hasil wawancara dengan guru PKn.

Seperti proses pembelajaran seperti biasa, saya dalam mengajar menggunkan berbagai metode, seperti ceramah, studi kasus, penugasan dan diskusi dengan memberikan contoh-contoh tentang nasionalisme dan patriotisme, seperti jika melestarikan dan menggunakan batik merupakan salah satu sikap cinta tanah air, sifat toleransi; dalam proses bergaul kita harus menghormati teman yang beragama lain utuk beribadah sesuai keyakinannya dan lain-lain (Mujito, Guru: Selasa, 1 Maret 2016).

Selain proses penanaman nilai melalui proses pembelajaran yang dilakukan dikelas nilai-nilai nasionalisme dan patriotisme juga di ajarkan dengan berbagai kegiatan lain yang ada disekolah, hal ini sesuai yang dikemukakan oleh Kepala Sekolah.

Ada berbagai cara, seperti yang saya kemukakan tadi seperti, menyanyikan lagu Indonesia raya saat akan mulai pelajaran dan menyanyikan lagu bernuansa patriotik/cinta tanah air baik lagu wajib nasional maupun lagu daerah sebelum berdoa saat mengakhiri pembelajaran, upacara bendera, penertiban terhadap siswa yang terlambat berangkat sekolah, peduli sosial yaitu menjenguk teman yang sedang sakit atau tertimpa musibah, sekolah juga mengadakan ekstrakulikuler yang mencerminkan kecintaan terhadap budaya Indonesia seperti ekstra karawitan dan silat. Dalam proses belajar mengajarpun anak-anak selalu dihimbau dan diajarkan untuk toleransi, kerjakeras, disiplin dan berani mengemukakan pendapat (Sartono, Kepala Sekolah: 1 Maret 2016).

Kegiatan-kegiatan yang dilaksanakan itu juga dikuatkan oleh beberapa hasil wawancara dengan siswa tentang kewajiban mengikuti upacara.

Tentu saja wajib, upacara selain untuk menghormati jasa pahlawan yang telah gugur juga meningkatkan kedisiplinan serta meningkatkan jiwa nasionalisme dan patriotisme (Sekar Purnamasari, Siswa: 29 Februari 2016).

Iya, karena sekolah ingin menciptakan rasa nasionalisme terhadap siswanya, agar para siswa tetap menghargai akan jasa pahlawan dan tidak melupakannya dengan bersamaan kemajuan IPTEK yang sangat pesat (Prashinta Dyah Fadlina, Siswa: 29 Februari 2016). 
Penertiban atau pendisiplinan terhadap siswa yang terlambat Iya. Karena dengan diberikan sanksi kita dapat disiplin dan mematuhi tata tertib sekolah (Dwi Kristanto, Siswa: 29 Februari 2016).

Iya, karena sekolah ingin menciptakan siswa yang tertib akan aturan disiplin dalam segala hal (Prashinta Dyah Fadlina, Siswa: 29 Februari 2016).

Sudah 70 tahun Bangsa Indonesia merdeka, melewati masa penjajahan dari Bangsa asing. Kurang lebih sekitar 350 tahun kekayaan dan sumber daya alam dikuasai oleh Bangsa asing. Setelah Bangsa Indonesia merdeka seperti saat ini bukan berarti generasi Bangsa tidak perlu dibekali lagi nilai nasionalisme dan patriotisme. Seiring perkembangan zaman dunia memasuki era baru yaitu era global, yang dibarengi dengan tumbuh pesatnya teknologi komunikasi tanpa batas. Selain itu Bangsa Indonesia juga baru saja memasuki MEA (Masyarakat Ekonoi Asia) dimana warga negara asing bebas masuk dan keluar serta bekerja di Indonesia, demikian juga masyarakat Indonesia juga bebas bekerja di negara lain di ASIA. Hal ini menjadi faktor utama dan penting terhadap pentingnya penguatan identitas Bangsa terhadap generasi penerus Bangsa, Sehingga mereka tetap cinta dan bangga serta dapat memajukan Bangsa Indonesia.

Selain hal tersebut, rasa cinta terhadap tanah air, rela berkorban, kesetiaan terhadap Bangsa serta keberanian membangun Bangsa saat ini sangat diperlukan oleh Bangsa dan negara ditengah maraknya penyelewengan yang dilakukan aparatur Bangsa dan oknum lain yang berusaha menguasai kekayaan Bangsa dengan cara yang tidak benar. Tujuan dari pentingnya penanaman nilai nasionalisme dan patriotisme ini sesuai dengan keterangan yang diberikan.

Agar siswa memiliki karakter yang baik, terutama cinta terhadap Bangsa dan negara, agar dapat membangun Bangsa ini sebagai Bangsa yang lebih baik. meski kelak mereka menjalani profesi masing-masing tetap memeberi kontribusi yang baik bagi Bangsa dan negara (Sartono, Kepala Sekolah: 1 Maret 2016).

Agar anak didik tetap memiliki sikap semangat nasionalisme dan patriotisme untuk menghadapi kemajuan teknologi yang semakin pesat (Sumarni, Guru: 1 Maret 2016).

Ya sangat penting, karena tanpa rasa nasionalisme dan patriotisme maka tidak ada rasa cinta terhadap Bangsa dan negara ini, dan akan semakin terpuruk untuk kemajuan negara ini (Prashinta Dyah Fadlina, Siswa: 29 Februari 2016).

Sangat penting, karena apabila warga negara tidak punya rasa nasionalisme dan patriotisme, negara yang ditingali akan hancur, karna warga negaranya sendiri tidak 
memiliki rasa kecintaan terhadap negaranya sendiri (Erdy Winarjo, Siswa: 29 Februari 2016).

2. Kendala-Kendala Dalam Penanaman Nasionalisme dan Patriotisme

Kendala penanaman nilai-nilai pendidikan karakter bagi siswa terutama nilai nasionalisme dan patriotisme dalam proses pembelajaran PKn pada materi sikap semangat kebangsaan, adalah sesuai dengan hasil wawancara dengan guru mata pelajaran PKn yaitu:

Khusus pada materi ini sikap semangat kebangsaan dan nasionalisme, kita dibatasi oleh alokasi waktu belajar. Karena materinya banyak sehingga kita arus mengikuti pada kurikulum yang sudah ada agar anak dapat menguasai materi yang lain, dan secara garis besar kendala pendidikan nasionaslisme dan patriotisme bagi siswa adalah minimnya keteladanan dari figur pemimpin negeri ini (Mujito, Guru: 1 Maret 2016).

Dari hasil wawancara tersebut yang menjadi kendala utama dalam proses penanaman nilai nasionalisme dan patriotisme adalah alokasi waktu pada materi sikap semangat kebangsaan, nasionalisme dan patriotisme. Selain itu minimnya figur yang dapat dijadikan suritauladan menjadi kendala secara umum untuk penanaman nilai nasionalisme dan patriotisme, hal ini sesuai degan yang dikemukakan oleh Kepala Sekolah: Kurangnya keteladanan (Sartono, Kepala Sekolah: 1 Maret 2016).

Era global yang ditandai dengan akulturasi bidaya yang mengubah cara pandang generasi muda khususnya pada siswa juga menjadi salah satu kendala karena hal itu secara disadari atau tidak mengubah cara pandang sebagian anak muda yang mengagumi budaya asing dan menganggap bahwa budaya dan tradisi budaya Bangsa sudah tidak zaman dan tidak sesuai dengan kehidupan masa kini. Hal ini sesuai yang diungkapkan ibu Sumarni.

Siswa menganggap bahwa nilai-nilai yang terdapat dalam nasionalisme dan patriotisme sudah tidak zaman lagi untuk dibicarakan dan dilaksanakan, sehingga perwujudan nilai luhur karakter sangat sulit diterapkan kepada siswa. Seiring dengan budaya asing yang masuk inilah yang menyebabkan siswa enggan untuk menampilkan sikap cinta tanah air dan sikap heroik sebagai penerus generasi muda. Kondisi siswa yang cenderung bersikap apatis sehingga banyak siswa yang membolos pada saat jam pelajaran sedang berlangsung, dan pada saat pelaksanaan upacara bendera setiap hari Senin siswa juga ada yang tidak mengikuti kegiatan tersebut (Sumarni, Guru: 1 Maret 2016). 
3. Usaha-Usaha Dalam Mengatasi Kendala-Kendala

Dalam rangka mengatasi kendala-kendala yang dihadapi dalam proses penanaman nilai nasionalisme dan patriotisme selain memasukkan pendidikan karakter pada setiap mata pelajaran sekolah juga mendukung dengan beberapa kegiatan ekstrakulikuler atau kegiatan-kegiatan rutin yang dapat merangsang dan menumbuhkan rasa nasionalisme dan patriotisme pada pribadi siswa. hal ini sesuai dengan hasil wawancara.

Karena pendidikan karakter tidak hanya terdapat dalam proses belajar mengajar pada materi sikap kebangsaan dan patriotisme sehingga kita dapat juga menanamkan nilai-nilai nasionalisme dan patriotisme melalui materi yang lain, tentunya materi yang dapat kita sisipkan dengan nilai-nilai nasionalisme dan patriotisme. Selain itu sekolah juga memberikan peraturan dan beberapa kegiatan yang dapat digunakan sebagai sarana penanaman nilai-nilai nasionalisme dan patriotisme (Mujito, Guru: 1 Maret 2016).

Upayanya yaitu bahwa setiap proses pembelajaran menyelipkan 18 pendidikan karakter. selain hal itu juga sekolah sangat mendukung terhadap pendidikan karakter bagi siswa untuk menimbulkan kembali rasa nasionalisme dan patriotisme contohnya upacara setiap hari senin, menyanyikan lagu Indonesia raya saat akan mulai pelajaran dan menyanyikan lagu bernuansa patriotik/cinta tanah air baik lagu wajib nasional maupun lagu daerah sebelum berdoa saat mengakhiri pembelajaran, menyelenggarakan ekstrakulikuler yang bisa merangsang nasionalisme dan patriotisme seperti pramuka, pencak silat, PMR, UKS dan beberapa kegiatan yang lain (Sumarni, Guru: 1 Maret 2016).

Untuk mengatasi hambatan tersebut dapat dilakukan dengan cara mengikuti upacara bendera, mengikuti lomba hari nasional mis: hari kartini, mengikuti LCC 4 Pilar Kebangsaan. Menyanyikan lagu Indonesia raya saat akan mulai pelajaran dan menyanyikan lagu bernuansa patriotik/cinta tanah air baik lagu wajib nasional maupun lagu daerah sebelum berdoa saat mengakhiri pembelajaran, mengadakan kegiatan jelajah museum di Yogyakarta (Sartono, Kepala Sekolah: 1 Maret 2016)

\section{SIMPULAN DAN SARAN}

\section{A. Simpulan}

Berdasarkan hasil penelitian mengenai penanaman nilai-nilai nasionalisme pada siswa di SMA Negeri 1 Pundong dapat ditarik kesimpulan sebagai berikut bahwa menanamkan nilai nasionalisme dan patriotisme harus dimiliki setiap generasi penerus Bangsa sebagai modal membangun dan bersaing di kanca internasional. 
Penanaman nilai-nilai tersebut dilaksanaan melalui berbagai macam strategi pembelajaran yang diintegrasikan ke dalam rencana pelaksanaan pembelajaran (RPP) dan dilaksanakan dengan berbagai metode ceramah, diskusi, dan tugas. Selain dalam proses pembelajaran nilai-nilai nasionalisme dan patriotisme juga dilaksanakan melalui berbagai kegiatan yang diadakan oleh sekolah secara langsung seperti upacara bendera, menyanyikan lagu Indonesia raya saat akan mulai pelajaran dan menyanyikan lagu bernuansa patriotik/cinta tanah air baik lagu wajib nasional maupun lagu daerah sebelum berdoa saat mengakhiri pembelajaran,mengikuti berbagai macam perlombaan misalnya : LCC 4 Pilar Kebangsaan, Pemilihan Kartini Kartono, memperingati hari-hari nasional dan berbagai kegiatan lainnya. Selain itu juga kegiatan penanaman nilai-nilai nasionalisme dan patriotisme juga melalui kegiatan-kegiatan yang berupa kegiatan ekstrakulikuler.

1. Dalam proses penanaman nilai-nilai nasionalisme dan patriotisme pada siswa menemui beberapa hambatan, secara umum hambatan tersebut yaitu kurangnya keteladanan dari figur pemimpin Bangsa yang ada saat ini. Secara khusus dalam proses pembelajaran yaitu minimnya jam pembelajaran pada materi materi sikap semangat kebangsaan nasionalisme dan patriotisme dalam kehidupan bermasyarakat, berbangsa dan bernegara.

2. Usaha untuk mengatasi hambatan dalam proses penanaman nilai-nilai nasionalisme dan patriotisme yaitu bahwa pada setiap proses pembelajaran diselipkan 18 pendidikan karakter dan kegiatan-kegiatan yang dilaksanakan di luar proses pembelajaran yang diselenggarakan oleh sekolah yaitu upacara bendera, menyanyikan lagu Indonesia Raya dan menyanyikan lagu daerah, memperingati hari-hari nasional dan berbagai kegiatan lainnya. Kegiatan yang berupa kegiatan ekstrakulikuler.

\section{B. Saran}

Berdasarkan kesimpulan dari hasil penelitian di atas, maka penulis memberikan beberapa saran sebagai berikut:

1. Dalam proses pembelajaran guru harus pandai dalam memilih metode pembelajaran yang efektif dalam rangka penanaman nilai-nilai nasionalisme dan patriotisme agar siswa lebih mudah dalam memahami dan dapat mengimplementasikan dalam kehidupan berbangsa dan bernegara.

2. Sekolah harus dapat menyelenggarakan kegiatan-kegiatan yang sifatnya edukatif dan dapat menjadi sarana penanaman nilai-nilai nasionalisme dan patriotisme.

\section{DAFTAR PUSTAKA}


Abdul Majid. 2013. Strategi Pembelajaran. Bandung: PT Remaja Rosdakarya offset.

Ali. 2015. Tawuran, Siswa SMK PGRI 2 Tewas Tertancap Samurai, tersedia: http://hariantangerang.com/news/2015/04/tawuran-siswa-smk-pgri-2-tewas-tertancapsamurai (3 September 2015).

Badan Standar Nasional Indonesia. 2016. Mata Pelajaran Pendidikan Kewarganegaraan untuk Sekolah Menengah Atas (SMA)/Madrasah Aliyah (MA), tersedia: http://bsnpindonesia.org/id/ (5 September 2015).

Budiyanto, dkk. 2006. Pendidikan Kewarganegaraan. Jakarta: Erlangga.

Chotib. 2006. Kewarganegaraan 1. Jakarta : Yudhistra.

Hans Kohn. 1984. Nasionalisme Arti dan Sejarahnya. Jakarta: Erlangga.

Indonesia Corrupton Watcth. 2014. Tren Pemberantasan Korupsi 2014, tersedia: http://www.antikorupsi.org/id/doc/tren-korupsi-2014 (3 September 2015).

Kony Fahran. 2014. Tawuran pelajar tewaskan 19 Pelajar Dalam Setahun, tersedia: http://beritakaltara.com/? $p=2100$ (3 September 2015).

Oemar Hamalik. 1994. Metode Pendidikan. Bandung : PT. Citra Aditya.

Sudarwan Danim dan Khairil. 2012. Profesi Kependidikan. Bandung: Alfabeta.

Sugiyono. 2012. Metode Penelitian Pendidikan Pendekatan Kuantitatif, Kualitatif, dan R\&D. Bandung: Alfabeta.

Suprapto, dkk. 2007. Pendidikan Kewarganegaraan. Jakarta: Bumi Aksara.

Syahrial Syarbaini. 2006. Membangun karakter dan Kepribadian Melalui pendidikan Kewarganegaraan. Jakarta: Graha Ilmu. 2011. Pendidikan Pancasila, Implementasi Nilai-Nilai karakter Bangsa di Perguruan Tinggi, Bogor: Ghalia Indonesia.

Tim Masmedia Buana pustaka. 2015. Pendidikan Kewarganegaraan Untuk SMA/MA Kelas X. Surakarta: Masmedia Buana Pustaka.

Tri Darmiyati. 2008. Pengaruh Globalisasi terhadap Nilai-Nilai Nasionalisme. Diambil dari www.wikimu.com, tanggal 10 September 2015.

Zainal Arifin. 2011. Penelitian Pendidikan Metode dan Paradigma Baru. Bandung: PT Remaja Rosdakarya Offset. 